\title{
A QUANTUM CHEMICAL ANALYSIS OF DEPENDENCE OF THE PROTOLYTIC PROPERTIES OF SILICA PRIMARY PARTICLES ON THEIR COMPOSITION AND SPATIAL STRUCTURE
}

\author{
A.A. Kravchenko, E.M. Demianenko, O.V. Filonenko, \\ A.G. Grebenyuk, V.V. Lobanov, M.I. Terets \\ Chuiko Institute of Surface Chemistry of National Academy of Sciences of Ukraine \\ 17 General Naumov Str., Kyiv, 03164, Ukraine, E-mail: kravchenkoandrew7@gmail.com
}

High disperse silica is used as a sorbent and carrier of medical preparations in various branches of medicine, biotechnology etc. due to its physico-chemical properties, in particular, rather developed surface, chemical inertness, considerable adsorption capacity. The protolytic equilibrium of silica surface is to be examined, because the structure of its hydroxylic layer determines its properties. When silicic acid is polymerized, an increase in the molecular mass of the particles formed and the acidic properties of oligomers are changed.

Keywords: density functional theory, silicic acids, fullerene-like molecules, $p K_{a}$.

\section{Intoduction}

There are many synthesized silica structures nowadays, such as silica films, nanotubes, nanospheres, nano-sized amorphous silica. They are industrially important materials widely used in catalysis, ion exchange, chromatographic separation; they are potentially important for synthesis of special-purpose materials. However, some physical and chemical aspects of silica nanoparticles formation have not yet been fully explained. The structure of crystalline and amorphous silica modifications is determined by peculiarities of the stage of formation of primary particles. There are still some questions despite considerable progress in theoretical and experimental study of nucleating stages. The mechanisms of primary particles condensation of the molecular level during the process of synthesis, thermodynamic and kinetic parameters of the stages of primary particles during that process have not yet been fully explained.

Most of silica materials are obtained by using sol-gel and hydrothermal method of synthesis. Polycondensation of orthosilicic acid molecules is the main chemical process during all the stages of the method, and we can write it down schematically using an equation:

$$
\equiv \mathrm{Si}-\mathrm{OH}+\equiv \mathrm{Si}-\mathrm{OH} \leftrightarrow \equiv \mathrm{Si}-\mathrm{O}-\mathrm{Si} \equiv+\mathrm{HOH} .
$$

Experiment shows that at the initial stages of sol-gel synthesis in solution during the first hours different oligomers are formed. The formed oligomers are as follows: dimers, linear trimers and tetramers, cyclic trimers and tetramers, prismatic hexamers, cubic octamers and other oligomers with more elaborated structure. The complexity in study of silicate solution and silica solutions is different comparing to polymeric hydrocarbon compounds because of the only fact any change of solution ( $\mathrm{pH}, T$, concentration) immediately leads to the changes in the polymer composition. Thereby, all the clearness in definition of polymer composition in solution of silicic acid has been not yet achieved. That is why so important to study the structure and properties of silica molecular forms which can be formed at the initial stages of synthesis.

Examination of the protolytic equilibrium at silica surface is important because the structure of the surface hydroxylic layer determines its properties. When silicic acid is polymerized, due to aggregation of particles with increase in their molecular masses, the acidic properties of the oligomers formed are also changed; this work is devoted to their examination.

The reaction of deprotonation of the silanol groups can be conceived of the following scheme:

$$
\equiv \mathrm{Si}-\mathrm{OH} \leftrightarrow \equiv \mathrm{Si}-\mathrm{O}^{-}+\mathrm{H}^{+} .
$$


When orthosilicic acid is polycondensed, an ${ }^{-} \mathrm{O}-\mathrm{Si}(\mathrm{OH})_{3}$ substitution takes place for $\mathrm{OH}^{-}$ one of $\mathrm{a} \equiv \mathrm{Si}-\mathrm{OH}$ group differing in electronegativity. Thus, in the course of polycondensation process, structural changes occur in newly formed oligomers capable to affect their acidic properties.

\section{Computational methods}

All the calculations have been carried out by semiempirical PM7 method as well as by density functional theory method (DFT) with exchange-correlation functonal B3LYP and valence-split basis set $6-31++\mathrm{G}(\mathrm{d}, \mathrm{p})$. The effect of aqueous medium was taken into account within the frameworks of a continual solvent model (PCM). All the computations have been realized by means of program packages US GAMESS [1] and MOPAC [2]. The deprotonation constant $p K_{a 2}$ has been evaluated by the formula: $p K_{a}=\Delta G_{\text {react. }} / 2.303 R T$, where $R$ - universal gas constant, $T$ - temperature, and $\Delta G_{\text {react }}$ - the Gibbs free energy of the deprotonation reaction.

\section{Results and discussion}

In [3] dissociation of orthosilicic acid molecule in aqueous solutions was examined by Hartree-Fock-Roothaan method as well as by density functional theory with functionals B3LYP and M06-2x and within the frameworks of Møller-Plesset second order perturbation theory with basis set $6-311++G(d, p)$. The thermodynamic and kinetic characteristics of the reaction of proton transfer from orthosiicic molecule to a water molecule of the hydrate cover have been calculated as well as the equilibrium constant $\left(p K_{a}\right)$ of this process. The the dissociation constant estimated from the calculations by DFT method with taking solvent effect into account (PCM) $\left(p K_{a}=9.5\right)$ have been shown to be the best fit to the experimental one in aqueous solutions (9.46). In [4] a quantum chemical analysis of the structures of the molecules of silicic acid oligomers was made by DFT method with use of expanded basis set $(6-31++\mathrm{G}(\mathrm{d}, \mathrm{p}))$ and the $p K_{a}$ values were computed for clusters including one to eight silicon-oxygen tetrahedra. The step-by-step increase in the number of tetrahedra in oliugomers has been found to decrease the value of the deprotonation constants $\left(p K_{a}\right)$ of silanol groups. The authors of [5] calculated ${ }^{29} \mathrm{Si}$ NMR spectra of fullerene-like hollow oligomers of silicic acid consisting of 1, 2, 4, 8, 10, and 20 siliconoxygen tetrahedra by DFT method with hybride exchange-correlation functional B3LYP and basis set $6-311+\mathrm{G}(2 \mathrm{~d}, \mathrm{p})$ with use of GIAO procedure.

This work is devoted to the examination of the protolytic properties of fullerene-like hollow oligomers as dependent on their dimensions and should be considered as a logical continuation of the article [4] (with increasing the number of silicon-oxygen tetrahedra in the models up to 60).

High disperse silica has a rather complicated structure. The primary particles with size of 5-100 $\mathrm{nm}$ are built of protoparticles with size of less than $1 \mathrm{~nm}$. In their turn, primary particles form agglomerates of aggregates with sizes of 1-50 $\mu \mathrm{m}$ [6]. A question arises, how can we simulate a silica particle. The HRTEM images of individual fumed oxides are shown in Fig. 1 a. The structure of a primary particle one can mimic by use of various composition of fullerene-like molecules as protoparticles. Thus, a model of primary particle is shown in Fig.1, b consisting of seven fullerene-like molecules $\mathrm{Si}_{60} \mathrm{O}_{90}(\mathrm{OH})_{60}$. According to the structural features of highdisperse silica, a set can be used of various size fullerene-like molecules with different structural and protolytic properties as a model for protoparticles. 


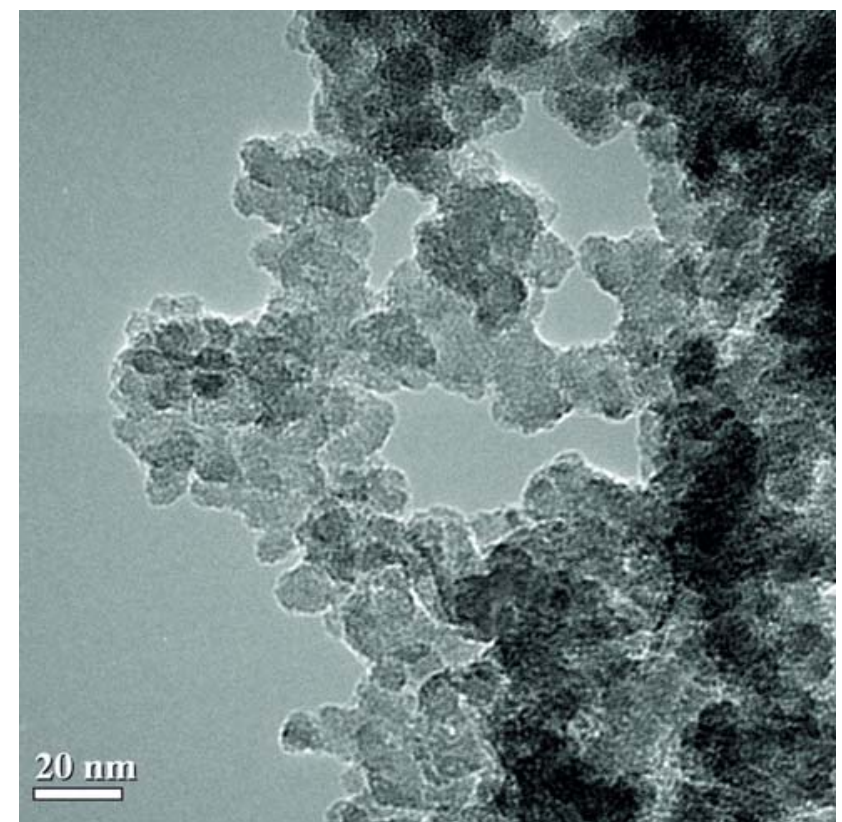

A

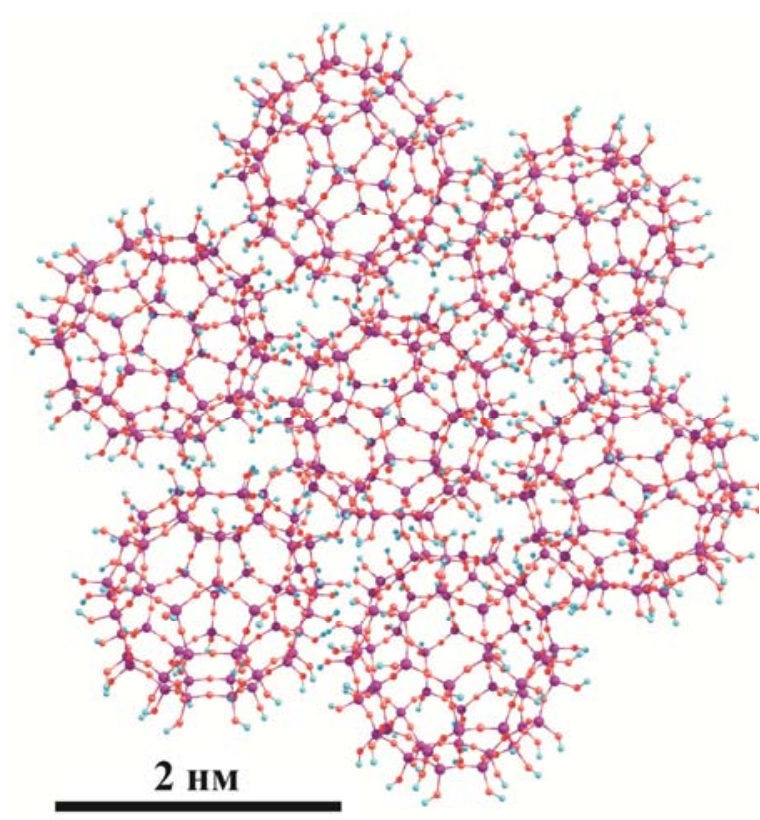

b

Fig. 1. HRTEM images of individual fumed oxides (a) A-300 [7] and model for primary particle built of fullerene-like species $\mathrm{Si}_{60} \mathrm{O}_{120}(\mathrm{OH})_{60}(\mathrm{~b})$.

Fullerene-like molecules $\mathrm{Si}_{\mathrm{n}} \mathrm{O}_{1,5 \mathrm{n}}(\mathrm{OH})_{\mathrm{n}}$ are structural analogues of carbon fullerenes where carbon atoms are substituted by tetrahedra $\mathrm{SiO}_{3}(\mathrm{OH})$. In Fig. 2 fullerene-like molecules are shown consisting of 10,20, 24 and 60 silicon-oxygen tetrahedra.
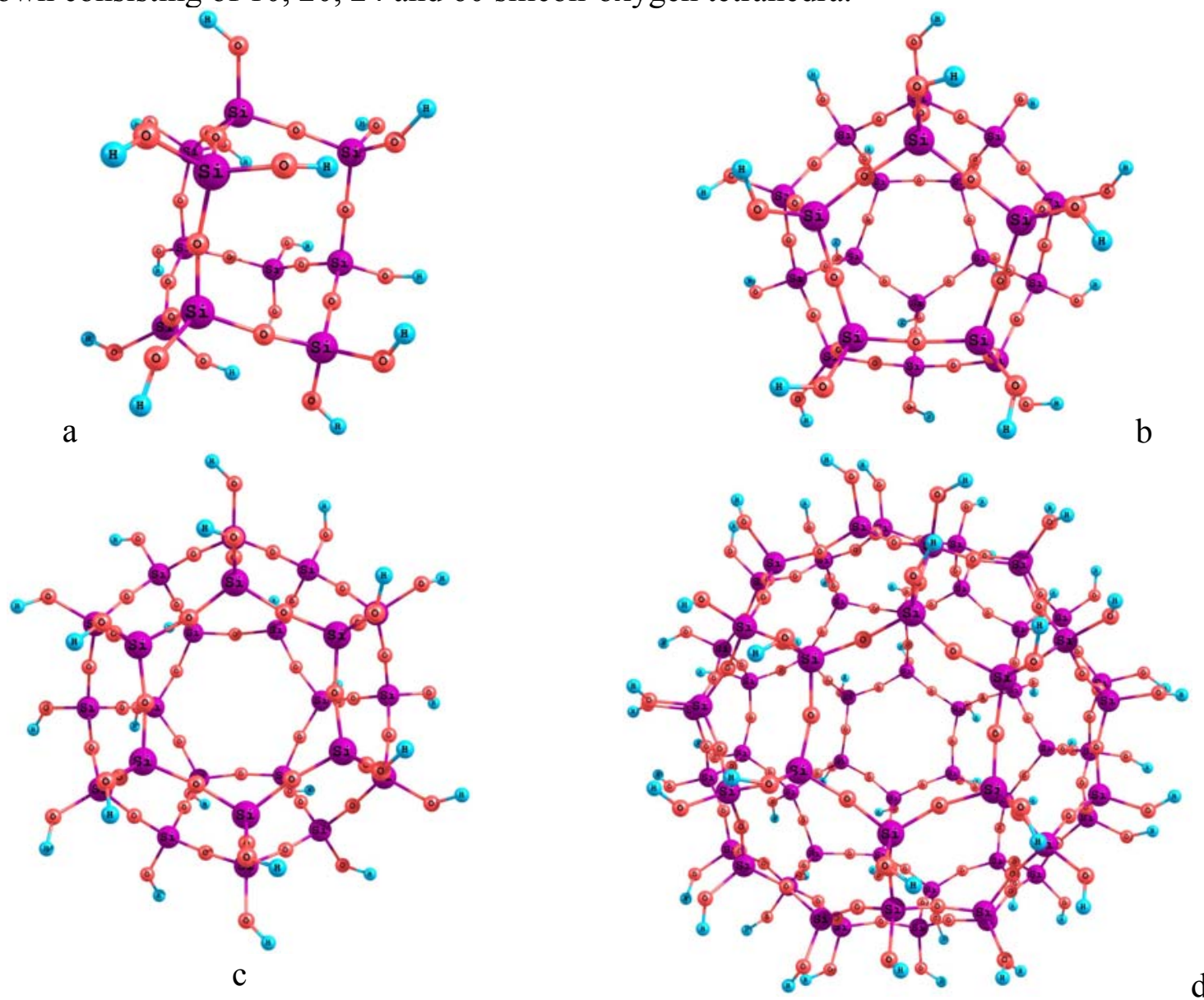

Fig. 2. Equilibrium structures of fullerene-like molecules: $a-\mathrm{Si}_{10} \mathrm{O}_{12}(\mathrm{OH})_{16}, \mathrm{~b}-\mathrm{Si}_{20} \mathrm{O}_{30}(\mathrm{OH})_{20}$, c - $\mathrm{Si}_{24} \mathrm{O}_{36}(\mathrm{OH})_{24}, \mathrm{~d}-\mathrm{Si}_{60} \mathrm{O}_{90}(\mathrm{OH})_{60}$. 
Besides the number of silicon-oxygen tetrahedra, the molecules mentioned differ also in the structural features of their arrangement. Thus, $\mathrm{Si}_{10} \mathrm{O}_{12}(\mathrm{OH})_{16}$ molecule is a cell with adamantane structure, in $\mathrm{Si}_{20} \mathrm{O}_{40}(\mathrm{OH})_{20}$ molecule tetrahedra form only pentagons whereas in $\mathrm{Si}_{24} \mathrm{O}_{36}(\mathrm{OH})_{24}$ molecule, besides pentagons, there are two opposite hexagons. In $\mathrm{Si}_{60} \mathrm{O}_{90}(\mathrm{OH})_{60}$ molecule silicon-oxygen tetrahedra form hexagons arranged around a pentagon. In order to understand the effect of structure and composition on the protolytic properties of silanol groups, a comparative analysis has been carried out of the changes in atomic charges of $\mathrm{a} \equiv \mathrm{Si}-\mathrm{OH}$ group as wellas in the $\mathrm{Si}-\mathrm{O}$ and $\mathrm{O}-\mathrm{H}$ bond lengths with increasing molecular sizes. As our computational possibilities give no opportunity to compare the parameters mentioned by means of density functional theory method, for calculations semiempirical PM7 method was used.

Simulation of the protolytic equiibrium of the silanol groups of silicic acid oligomers was realized with use of two systems of the same composition as models differing as follows: in the first one, a silanol group was surroubded by a cluster of water molecules (Fig. 3 a), in the second one the proton of silanol group was separated from its oxygen atom for about $4 \AA$ (Fig. 3 b). When optimizing the structures of these systems, a potential barrier was localized between them and hydronium cation was formed in the second system due to the proton transfer within the chain of water molecules: $\mathrm{SiO}^{-} \cdots \mathrm{H}_{2} \mathrm{O} \cdots \mathrm{H}_{2} \mathrm{O} \cdots{ }^{+} \mathrm{H}_{3} \mathrm{O}$. In such a way charge-separation complexes were obtained on the silanol groups of all the oligomers studied.
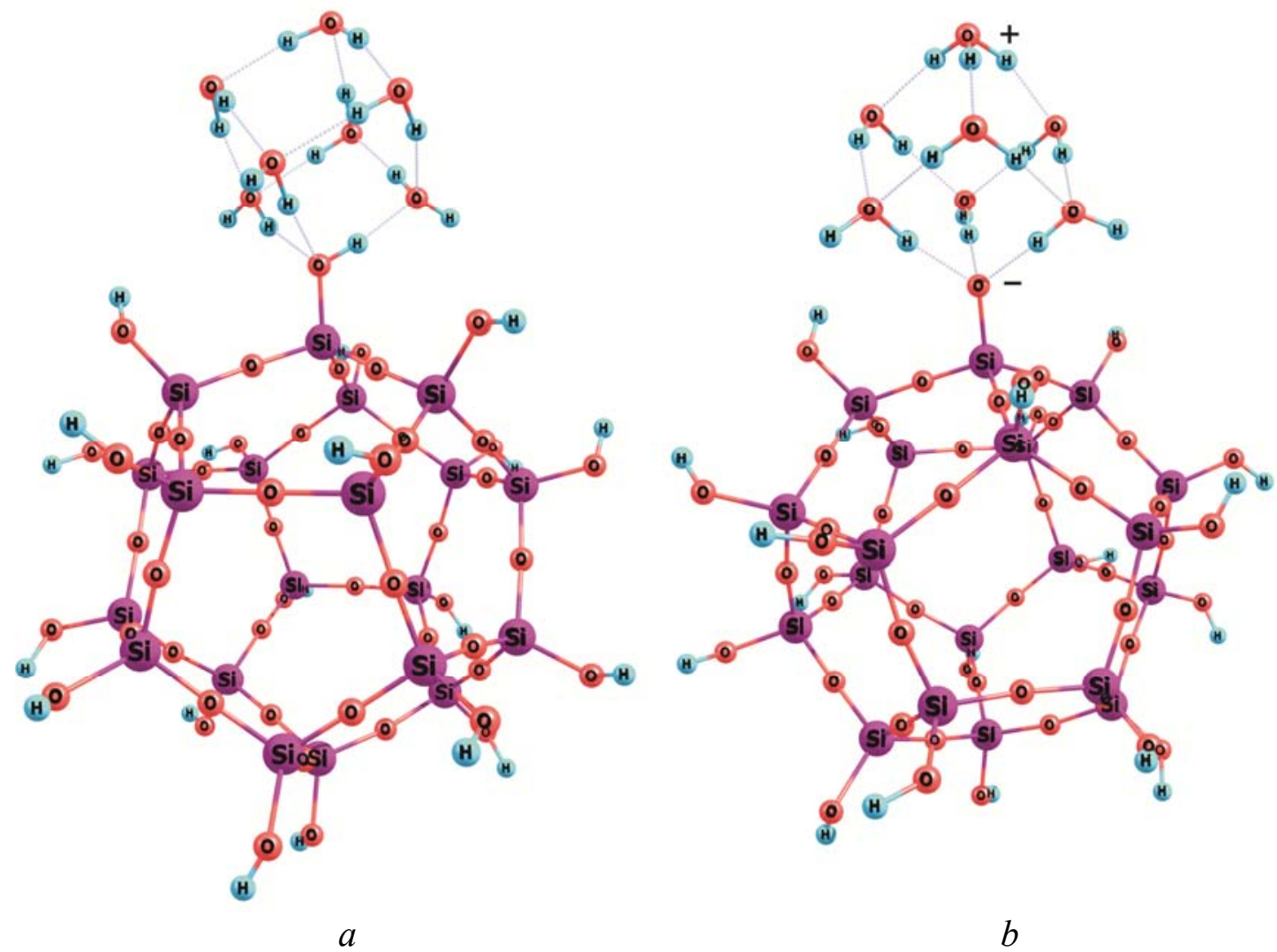

Fig. 3. Equilibrium structures of a $\mathrm{Si}_{20} \mathrm{O}_{30}(\mathrm{OH})_{20}$ molecule interacting with seven water molecules in the molecular state $(a)$ and in the carge-separated state $(b)$.

The changes in the atomic charges of hydrogen, oxygen, and silicon of silanol group as well as in the $\mathrm{Si}-\mathrm{O}$ and $\mathrm{O}-\mathrm{H}$ bond lengths with increasing number of atoms in the molecule have a complicated character but as a whole, show a similar tendency to changes. When the number of silicon-oxygen tetrahedra in the molecules increases, an increase in atomic charges takes place on hydrogen, oxygen, and silicon (Fig. 4, a, b, c). Simultaneously the $\mathrm{Si}-\mathrm{O}$ bond length increases and the $\mathrm{O}-\mathrm{H}$ bond length decreases (Fig. 4, d, i). The changes in calculated $p K_{a}$ values are 
irregular and, as a whole, manifest a tendency to a decrease with increasing molecular sizes (Fig. $4, \mathrm{f})$.
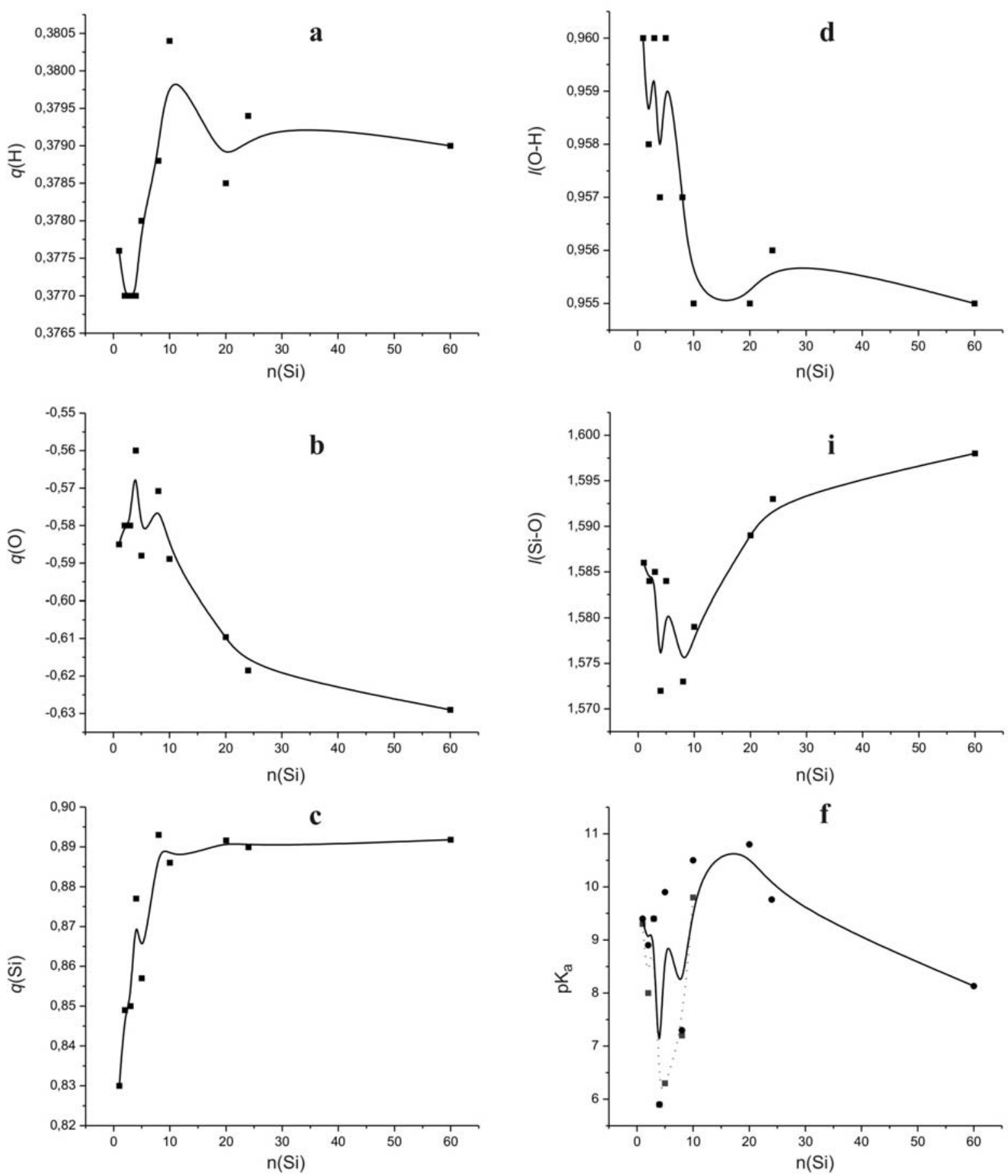

Fig. 4. Plots of hydrogen (a), oxygen (b) and silicon (c) atomic net charges, of O-H (d) and Si-O (i) bond lengths as well as of $\mathrm{pK}_{\mathrm{a}}$ values (f) on the number of silicon atoms in the molecules.

The value of Gibbs free energy for deprotonation decreases from orthosilicic acid to disilicic acid, then increases for the trimer, then decreases once more for the complexes with tetramer $\mathrm{Si}_{4} \mathrm{O}_{13} \mathrm{H}_{10}$ and pentamer $\mathrm{Si}_{5} \mathrm{O}_{14} \mathrm{H}_{12}$. Those values found by $\mathrm{PM} 7$ method agree well with findings by DFT method. The deprotonation constants for silanol groups $\left(p K_{a}\right)$ change symbately to the changes in the free Gibbs energy and, as a whole, decrease with an increase in the polymerization degree. 

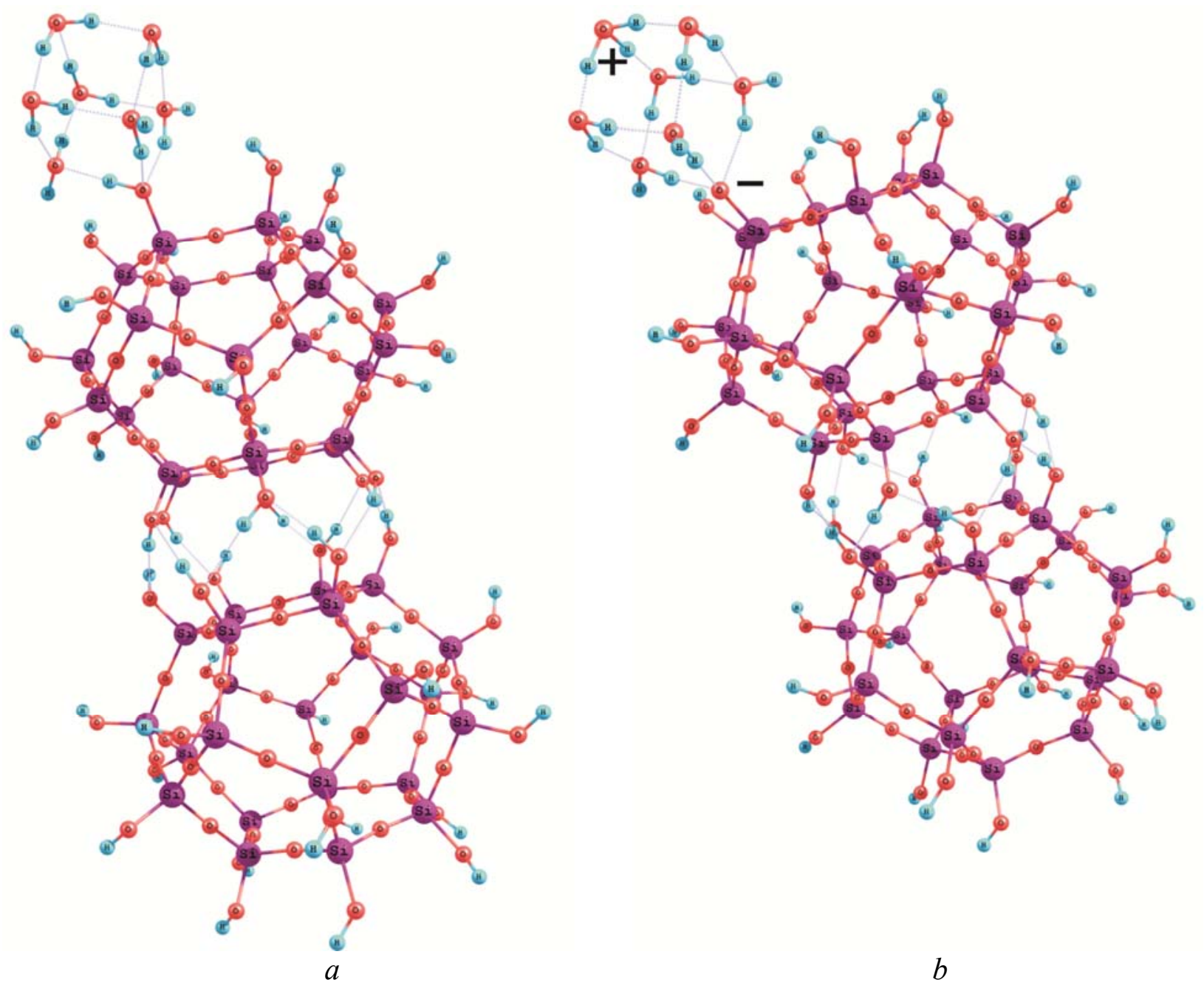

Fig. 5. Equilibrium structures of a pair of $\mathrm{Si}_{24} \mathrm{O}_{36}(\mathrm{OH})_{24}$ molecules interacting with seven water molecules in the molecular state $(a)$ and in charge-separated $(b)$

The calculated $\mathrm{pK}_{\mathrm{a}}$ value for the complex built by two $\mathrm{Si}_{24} \mathrm{O}_{36}(\mathrm{OH})_{24}$ molecules contacting via hydrogen bonds by faces formed by six silicon-oxygen tetrahedra is equal to 11.8 . The net charge on the silicon atom of the silanol group contacting with water molecules is equal to 0.89 whereas those on the oxygen atom and on the hydrogen atom are equal to -0.70 and 0.41 respectively. The $\mathrm{pK}_{\mathrm{a}}$ value for the complex of three $\mathrm{Si}_{24} \mathrm{O}_{36}(\mathrm{OH})_{24}$ molecules is equal to 3.8.

It should be noted that taking into account the effect of solvent decreases the $\mathrm{pK}_{\mathrm{a}}$ value. Thus, the calculated solvent-free finding for the complex including 60 silicon atoms is equal to 12.2 whereas analogous value accepting solvent effect equals to 8.3.

The calculated $\mathrm{pK}_{\mathrm{a}}$ values for the complex of two $\mathrm{Si}_{60} \mathrm{O}_{90}(\mathrm{OH})_{60}$ molecules without solvent effect is equal to 3.3.

\section{Conclusion}

Starting from the results of calculations of the equilibrium structural and enegy parameters of the hydrated complexes of silicic acids, one can assert that a step-by-step increase in the number of silicon-oxygen parameters in the oligomer results in shortening of interatomic bonds and in changes of atomic net charges what is reflected in a decrease in the value of deprotonation of silanol groups $p K_{a}$. In turn, an increase in the number of contacting molecules leads to the growth in of $p K_{a}$ value. The accordance of the calculated deprotonation constants of silanol groups as dependent on the of polycondemsation of silicic acid with respective experimental data support a probability of use of the complexes considered for simulation of the deprotonationprotonation processes occuring on silica surface. 


\title{
References
}

1. Schmidt M.W., Baldridge K.K., Boatz J.A. et al. General atomic and molecular electronicstructure system: Review // J. Comput. Chem., 14 (1993) 1347.

2. Stewart J.J.P. MOPAC 2012, Colorado Springs, CO, Stewart Computational Chemistry, USA, http://openmopac.net/, 2014.

3. Demianenko E., Ilchenko M., Grebenyuk A., Lobanov V. A theoretical study on orthosilicic acid dissociation in water clusters, Chem. Phys. Lett., 515 (2011) 274.

4. Кравченко А.А., Демяненко Є.М., Гребенюк А.Г., Лобанов В.В. Квантовохімічне моделювання протолітичної рівноваги поверхні кремнезему. Хімія, фізика та технологія поверхні, 5 (2014) 16.

5. Filonenko O.V., Kuts V.S., Terebinska M.I., Lobanov V.V. Quantumchemical calculation of ${ }^{29} \mathrm{Si}-\mathrm{NMR}$ spectrum of silicon dioxide fullerene-like molecules, Chemistry, Physics and Technology of Surface, 6 (2015) 263.

6. Кластеризация воды и пути ее использования, В.В. Туров, В.М. Гунько. - Киев: Наукова думка, 2011. - 314 с.

7. V.M. Gun'ko, V.I. Zarko, O.V. Goncharuk et al. Nature and morphology of fumed oxides and features of interfacial Phenomena, Applied Surface Science, 366 (2016) 410-423.

\section{КВАНТОВОХІМІЧНИЙ АНАЛІЗ ПРОТОЛІТИЧНИХ ВЛАСТИВОСТЕЙ ПЕРВИННИХ ЧАСТИНОК КРЕМНЕЗЕМУ ВІД ЇХНЬОГО СКЛАДУ ТА ПРОСТОРОВОЇ БУДОВИ}

\author{
Кравченко А.А., Дем'яненко Є.М., О.В. Філоненко, Гребенюк А.Г., \\ Лобанов В.В., М.I. Терець \\ Інститут хімії поверхні ім. О.О. Чуйка Національної академії наук Украӥни, \\ вул. Генерала Наумова, 17, Київ, 03164, Украӥна
}

\begin{abstract}
Високодисперсний кремнезем завдяки своїм унікальним властивостям набув широкого використання як сорбент та носій лікарських засобів в різних галузях медицини, біотехнології тощо. Для розробки нових сорбентів на основі кремнезему необхідно добре розуміти механізми протонного обміну, що відбуваються в його поверхневому гідрокси-гідратному шар, $i$ на молекулярному рівні. Напівемпіричним методом РМ7 та методом функиіоналу густини $з$ використанням розширеного базисного набору (6-31++G(d,p)) проведено квантовохімічний аналіз будови фулереноподібних порожнистих молекул. Розраховані константи дисоціації гідроксильної групи для молекул, що містять від одного до шестидесяти силіцій-кисневих тетраедрів. Виявлено, щуо при постадійному збільшенні кількості останніх в олігомерах зменшується величина константи депротонування силанольних груп $\mathrm{pK}_{a}$.
\end{abstract}




\title{
КВАНТОВОХИМИЧЕСКИЙ АНАЛИЗ ПРОТОЛИТИЧЕСКИХ СВОЙСТВ ПЕРВИЧНЫХ ЧАСТИЦ КРЕМНЕЗЕМА ОТ ИХНЕГО СОСТАВА И ПРОСТРАНСТВЕННОГО СТРОЕНИЯ
}

\author{
Кравченко А.А., Демьяненко Е.М., О.В. Филоненко, Гребенюк А.Г., \\ Лобанов В.В., Терець М.И.
}

Институт химии поверхности им. А.А. Чуйко Национальной академии наук Украинь,, ул. Генерала Наумова, 17, Киев, 03164, Украина

\begin{abstract}
Высокодисперсный кремнезем благодаря своим уникальным свойствам получил широкое использование как сорбент и носитель лекарственных средств в различных областях медицины, биотехнологии и т. Для разработки новых сорбентов на основе кремнезема необходимо хорошо понимать механизмы протонного обмена, происходящие в его поверхностном гидроксигидратной слое на молекулярном уровне. Полуэмпирическим методом РМ7 и методом функиионала плотности с использованием расширенного базового набора $(6-31++G(d, p))$ проведен квантовохимический анализ строения фуллереноподобных полых молекул. Рассчитаньи константы диссочиачии гидроксильной группь для молекул, содержащих от одного до шестидесяти кремний-кислородных тетраэдров. Обнаружено, что при постадийном увеличении количества последних в олигомеры уменьшается величина константы депротонирования силанольних групп $p K_{a}$.
\end{abstract}

